BEATA KACZMARCZYK

ORCID: 0000-0001-5313-5281

Uniwersytet Wrocławski

Wydział Filologiczny, Instytut Filologii Polskiej

\title{
Nazwy powinności feudalnych, opłat i danin w akcie przekazania zamku w Ostrogu na Wołyniu z 1542 roku
}

\begin{abstract}
Abstrakt
Podstawą źródłową artykułu jest akt przekazania zamku w Ostrogu na Wołyniu z 1542 roku wpisany do Metryki Koronnej nr 65. Rękopiśmienny dokument zawiera interesujące słownictwo dotyczące kultury materialnej i społeczno-gospodarczej opisywanych terenów. W artykule przedstawiono tę część leksyki, która służyła nazywaniu powinności feudalnych, danin i opłat. Obok terminów powszechnie używanych w tym czasie w Polsce omówiono także wyrazy rzadkie i formy regionalne, charakterystyczne dla ziem litewsko-ruskich, które wcześniej w opracowaniach leksykograficznych nie zostały udokumentowane dla XVI wieku.
\end{abstract}

Słowa kluczowe: leksykografia historyczna, słownictwo specjalistyczne, regionalizmy, nazwy powinności, polszczyzna kresowa, Wołyń.

Przechowywane w Archiwum Głównym Akt Dawnych w Warszawie księgi kancelarii królewskiej, zwane Metryką Koronną, są niezwykle cennym źródłem do dziejów języka polskiego. Prowadzono je po łacinie, ale już na początku XVI wieku sporadycznie zaczynają się w nich pojawiać również wpisy w języku polskim. Tylko niewielka ich część włączona została do kanonu źródeł Słownika polszczyzny XVI wieku. Z ksiąg wpisów, których sygnatury rozpoczynają się literami MK, są to teksty do roku 1540 (por. SPXVI: 1, LXXV). Interesujący nas dokument, opatrzony łacińskim nagłówkiem Actus Lithuanicus occasione castri Ostrog, datowany w Ostrogu 6 lutego 1542 roku, został umieszczony w księdze wpisów podkanclerzego Samuela Maciejowskiego oznaczonej sygnaturą MK 65․ Wpis liczy 28 stron i zajmuje karty od 350 v. do 364. Stan księgi jest dobry, oprawa współczesna, pismo staranne.

\footnotetext{
${ }^{1}$ http://agadd2.home.net.pl/metrykalia/MK/0065/ (dostęp: 10.12.2020).
} 
Miasto i zamek, Ostróg leżące w dawnym województwie wołyńskim, w 1542 roku znajdowały się w granicach Wielkiego Księstwa Litewskiego. Dokumenty pochodzące z tego obszaru rejestrowano wówczas w Metryce Litewskiej, która prowadzona była po rusku. Województwa wołyńskie, kijowskie i podlaskie zostały włączone do Korony w 1569 roku na mocy traktatów związanych z Unią Lubelską. Początkowa odrębność tych terenów, a w szczególności urzędowy język ruski, przyczyniły się do utworzenia w ramach Metryki Koronnej odrębnej serii, zwanej Metryką Ruską lub Metryką Wołyńską ${ }^{2}$. Prezentowany w tym artykule dokument nie bez przyczyny został jednak sporządzony w języku polskim, a następnie wprowadzony do Metryki Koronnej. W akcie zrelacjonowano przebieg przekazania zamku w Ostrogu Beacie z Kościelca, „małżonce nieboszczyka księdza Iliego Konstantynowicza Ostrogskiego - jak czytamy w dokumencie — i dziewce Ich Miłości, księżnie Elżbiecie [...] od księdza Wasyla Jego Miłości Konstantynowicza” zgodnie z postanowieniem dekretu ustalonego wcześniej przez rozjemców i potwierdzonego przez Zygmunta I. Dekret ten miał zakończyć toczący się spór o spadek po zmarłym księciu Ilii.

Na podstawie Herbarza Kaspra Niesieckiego udało się ustalić, że wspomniany książę Ilia to Eliasz Konstantynowicz Ostrogski ${ }^{3}$, syn wojewody trockiego i hetmana litewskiego Konstantego Ostrogskiego, a książę Wasyl ${ }^{4}$ to młodszy syn hetmana Ostrogskiego z drugiego małżeństwa, przyrodni brat Ilii. Z kolei Beata z Kościelca, córka podskarbiego Andrzeja Kościeleckiego i Katarzyny Telniczanki ${ }^{5}$, dawnej kochanki Zygmunta Starego, była wychowanką królowej Bony (por. Żelewski 1973: 222-224). Ślub Beaty z księciem Ilią odbył się na dworze królewskim dzień po zaślubinach królewny Izabeli z Janem Zapolyą. Na mocy testamentu księcia Ilii opiekę nad jego dobrami sprawował Zygmunt I z królową Boną (Przeździecki 1868: 61).

${ }^{2}$ I. Sułkowska-Kurasiowa, M. Woźniakowa, http://www.agad.gov.pl/inwentarze/Metr_Korx.xml\# series5 (dostęp: 03.01.2021)

3 „Ilia albo Eliasz książę Ostrogski, syn starszy Konstantyna kasztelana Wileńskiego i hetmana Litewskiego, torem ojca swego idąc z bratem swoim nieraz Tatarskie zagony zwycięzko rażąc, gdy w najlepszą do sławy nabycia zmierza, i fortuną i inszemi natury darami zmocniony, w rychle świat, i zamierzone od siebie nadzieje pożegnał w roku 1539. [...] Złączył się był dożywotnie z Beatą Kościelecką, córką Jędrzeja podskarbiego wielkiego koronnego i kasztelana Wojnickiego, z której córka tylko jedynaczka, Halszka albo Elżbieta, wielu w Polszcze rewolucyi, dla znacznych od siebie konkurrencyi okazyą była" (Herbarz polski 1841: 7, 182). Z kolei Roman Żelewski zwraca uwagę, że Ilia Ostrogski (1510-1539) „przebywając często na dworze królewskim (możliwe, iż także w latach chłopięcych był tam przez ojca oddany), przesiąkł polska kulturą, opanował język polski i łacinę" (Żelewski 1979: 480-481).

${ }^{4}$ Konstanty Wasyl Ostrogski (ok. 1526-1608), marszałek ziemi wołyńskiej, wojewoda kijowski (por. Chynczewska-Hennel 1979: 489-495).

${ }^{5}$ Katarzyna Kościelecka z d. Ochstat, zwana też Telniczanką, kochanka Zygmunta I, z którym miała syna Jana (ur. 1499), biskupa wileńskiego, a później poznańskiego, córki Reginę i Katarzynę. Z kolei z małżeństwa z Andrzejem Kościeleckim urodziła syna nieznanego imienia, zmarłego w dzieciństwie, oraz córkę Beatę, żonę księcia Ilii Ostrogskiego, a następnie Olbrachta Łaskiego, wojewody sieradzkiego. „Współczesna plotka, powtórzona później przez kilku historyków, jakoby Beata, urodzona już po śmierci Kościeleckiego, była córką królewską, wydaje się bezpodstawna wobec testamentu podskarbiego, wykazującego dużą troskę o mające przyjść na świat dziecko" (Świeżawski 1968-1969: 397-398). 
Król wyznaczył każdej ze stron sporu reprezentanta. W imieniu księżnej Iliny zamek odbierał Jan Lutomirski ${ }^{6}$, a księcia Wasyla reprezentował Szymon Babiński. Przekazanie zamku odbywało się od 30 stycznia do 6 lutego 1542 roku. Po zakończeniu czynności został sporządzony dokument w dwóch egzemplarzach, po jednym dla każdej ze stron, podpisany przez uczestników oraz świadków zdarzenia, a następnie potwierdzony i zarejestrowany w Metryce Koronnej.

W akcie zostały szczegółowo zrelacjonowane sposób przekazywania zamku oraz przebieg kontroli i rozliczenia stanu przynależnych do niego majętności. Dokument zawiera interesujące słownictwo dotyczące kultury materialnej i społecznej opisywanych terenów. Leksyka odnosząca się do kultury materialnej zostanie omówiona w odrębnym opracowaniu; w niniejszym artykule przedstawimy nazwy powinności feudalnych, opłat i danin, z których większość, niestety, występuje bez szerszego kontekstu. Wynotowane leksemy zostaną porównane ze słownikami języka polskiego oraz z innymi opracowaniami historycznojęzykowymi i historycznymi.

Należy podkreślić, że przybyli do Ostroga przedstawiciele królewscy, dokonując stosownych rozliczeńnie nie tylko opierali się na istniejących dokumentach, lecz także zdobywali wiadomości od miejscowych urzędników oraz innych informatorów, niekiedy bardzo nisko postawionych w drabinie społecznej ${ }^{7}$, czego liczne ślady odnajdujemy w omawianym tu akcie, na przykład:

ja Lutomirski przy tych to paniech wyżej pisanych przyjmowałem liczbę [czyli 'rozliczenie' przyp. B.K.] od urzędnikow folwarkowych i tywonow i tudzież od Żydów [...] i też ode wszytkich poddanych niższych ostroskich co ze wszelakich dochodow roku tysiącznego pięćsetnego czterdziestego pirwego od świętego Bartłomieja blisko przyszłego dali tym to urzędnikom ostroskim... (k. 356 v.-357)

albo w innym miejscu:

a tak my Lutomirski i Babinski z pany wyżej pisanymi takosmy postanowili od dnia pierwego februaryja abysmy wszytkich poddanych ostroskich już pod przysięgą słuchali i pytali, co ktory $\mathrm{z}$ nich dał księdzu Wasylowi i urzędnikom jego m(iłości) ostroskim po świętym Bartłomieju blisko przyszłym z dochodow jakichkolwiek, żebysmy tego dość mogli, czego by sie księdzu Wasylu jego M(iłości) księżna Iljina podle dekretu jednackiego upominać miała. (k. 357-357 v.)

W funkcji hiperonimu określającego wszelkie świadczenia związane z poddańczą pozycją społeczną autorzy dokumentu z Ostroga posługiwali się leksem powinność (por. SPXVI: 29, 175): „a ktemu zamku oddali mi thez mianowithe imienie zamkowe czerkowne i Boiarfkie nizei mianovane ze wffitkiemi boiari poddanimi, włafnofcziami, scherokofcziami i powin nofcziami” $(\mathrm{k} .352 \mathrm{v})^{8}$. W tej sa-

${ }^{6}$ Jan Lutomirski h. Jastrzębiec (zm. 1567), podskarbi nadworny, kasztelan sieradzki (por. Kowalska 1973: 139-141).

${ }^{7} \mathrm{~W}$ podobny sposób zdobywali informacje lustratorzy, którzy począwszy od 1564 roku przeprowadzali lustracje dóbr królewskich. Pozostawione przez nich protokoły lustracji uznawane są powszechnie za bezcenne źródło do badań zarówno historycznych, jak i językowych (por. Zajda 2007: 54).

${ }^{8} \mathrm{~W}$ cytatach ilustrujących wystąpienia leksemów omawianych w artykule zachowuję oryginalną pisownię rękopisu. 
mej funkcji został użyty także rzeczownik powi nowatość, który według ustaleń leksykografów w znaczeniu 'to, co należy zrobić, wypełnić, powinność' w XVI wieku miał zdecydowanie niższą frekwencję (por. SPXVI: 29, 195); ilustracją jego wystąpienia jest następujący fragment protokołu: „pothim siola czerkiewne z manaftiri i z ludzmi ich i infchimi wlafnofcziami i powinowat ofcziami” (k. 353). Ogólne znaczenie 'zysk, wpływ, przychód, pożytki (głównie pieniężne), a także podatek' wiązał się z kolei z rzeczownikiem do chod (por. SPXVI: 5, 212), który pojawił się samodzielnie, jak na przykład w podanym fragmencie dokumentu: „a jefliby czo dochodow iakichkolwiek vibrali przez then czaf, zebi mi liczbą vcziniwfchi wroczili wffithko" (k. 354), ale też w połączeniu szeregowym z wyrazem płat 'danina, podatek' (SPXVI: 24, 395), co ilustruje zdanie:

mowilem thim tho vrządnikom oftrofkim Tupilowi i Raiewiczowi abi mi oddali dochodi i plati wflithki spelna ktore ku zamku oftrofkiemu przisluffaią od swiąthego Barthlomieia blisko przefllego $\mathrm{i}$ infche rzeczi w zamku, w pafniach i w mliniech podlie decretu thego iednaczkiego. (k. 354)

Omówienie nazw określonych powinności rozpoczniemy od terminów stosowanych w odniesieniu do czynszu, raty dzierżawnej; w tej funkcji wystąpił rzeczownik arenda, co ilustruje przykład:

a czo fie dothiczi Mlinu pod zamkiem oftrofkim ktorÿ nieopatrznofczią a niedbalofczią Vrzandnikow Xiądza Wafila ie(g)o m(iłości) oftrofkich dnia fcheftnaftego Ianuaria zgorzal, czo zrazicz bądzie zidom $z$ arendi czo skodi poki thego Mlina nie zbuduÿą albo thez za naklad Xiąznie iei M(iłos)czi Iliinei czo na Budowanie thego Mlinu nalozi. (k. 360- 360 v.)

Leksem arenda obecny jest w polszczyźnie od XVI wieku i w interesującym nas znaczeniu notują go następujące słowniki: SPXVI: 1, 210, L: 1, 27, ESJPXVII, SWil: 29, SW: 1, 56, SJPD.

Opisując rozliczenia, autor dokumentu wykorzystał także termin naje m w znaczeniu 'opłata za wynajęcie, czynsz, wynagrodzenie za użytkowanie czyjejś własności’: „a xiandz Vafil ie(go) m(iłość) podle kwithow fwoich i vrządnikow fwoich od thich to zidow ku ktorim kwitom Raiewicz pifarz oftroski prziznal fie, wziął na then naÿem trzifta sefczdziefianth i ofm kop moneti Litewskiei" (k. 360). Wyraz ten notowany jest już w Sstp: 5, 48, a następnie w SPXVI: 15, 561, L: 3, 239, SWil: 715, SW: 3, 77, SJPD.

Kolejna nazwa, komorne, jest genetycznym przymiotnikiem derywowanym od podstawy rzeczownikowej i oznacza 'opłatę, czynsz płacony od wynajęcia komory, tj. mieszkania’ (Zajda 1970: 115). Leksem ko mor ne obecny jest w polszczyźnie od XVI wieku, ale w SPXVI został potwierdzony zaledwie jednym przykładem z Inwentarzy mieszczańskich z ksiag miejskich Poznania z 1553 (SPXVI: 10, 512). Termin ten rejestrują także następujące słowniki: L: 2, 419; Swil: 514, SW: 2, 422, SJPD. Wystąpienie leksemu ko mor ne w akcie przekazania zamku w Ostrogu zaświadcza ten oto fragment dokumentu:

a gdi lidzbą ÿuz vczinili z niektorich dochodow od swiathe(g)o Barthlomieia blifko prziflego, i zoftali na thei lidzbie tho ieft podimfczizni, komornego, laziebnego, strozewfczizni, prochowfczizni, 
mieifkich i sielfkich wirzędu i kunicznego kop ofmdziedziefianth i ofm grofi siedm, i ofm pieniadzii. (k. 359-359 v.)

Cytowane zdanie posłuży nam jeszcze do udokumentowania innych rzadkich nazw powinności, które to nazwy w dalszej części artykułu zostaną omówione w podanej kolejności: łaziebne, podymszczyzna, strożewszczyzna, prochowszczyzna, wyrząd oraz kuniczne. Pierwsza forma, łaziebne, oznaczała 'opłatę za korzystanie z łaźni lub czynsz płacony od niej przez właściciela, tj. łaziebnika’ (Zajda 1970: 124). Choć leksykografowie potwierdzili wystąpienie tego terminu zapisem z 1464 roku (por. Sstp: 4, 106), to z XVI wieku jak dotąd znane jest tylko jedno jego użycie pochodzące $\mathrm{z}$ Lustracji województwa sandomierskiego 1564-1565 (por. SPXVI: 12, 533). W tejże Lustracji w analogicznym znaczeniu została użyta również forma „łazienne”, ale i dla niej nie są znane inne konteksty z XVI wieku. Poza tym leksem łaziebne jest notowany w następujących słownikach: L: 2, 605, ESJPXVII jeszcze bez podanej definicji, SWil: 607, SW: 2, 803.

$\mathrm{W}$ cytowanym zdaniu $\mathrm{z}$ wołyńskiego dokumentu uwagę zwracają nazwy utworzone charakterystycznym dla terenów wschodnich sufiksem -szczyzna, takie jak podymszczyzna, strożewszczyzna oraz prochowszczyzna. Forma podymszczyz n a w Sstp została udokumentowana zapisem już z 1389 roku i objaśniona definicją: '(na Rusi Czerwonej) danina na rzecz panującego uiszczana od zagrody czyli dymu, tak zwane podymne' (Sstp: 6, 287). Na tę chwilę leksykografowie nie odnotowali jednak żadnego użycia tego wyrazu w XVI wieku (por. SPXVI: 26, 114). SPXVI podaje jedynie formę „podymne”, znaną z innych regionów Polski. Spośród opracowań leksykograficznych jedynie SW: 4,442 zamieszcza omawiany leksem.

Z kolei leksem strożewszczyzna, będący regionalną nazwą daniny, znanej jako „stróżne” - 'rodzaj opłaty składanej jako ekwiwalent powinności odbywania stróży” (por. hasło „strożne” w: Zajda 1970: 189), nie występuje ani w Sstp, ani $\mathrm{w}$ indeksie haseł Słownika polszczyzny XVI wieku (hasła rozpoczynające się literą s nie zostały jeszcze opracowane). Jedynie SW rejestruje hasło „stróżowszczyzna” 'opłata, danina na utrzymanie stróża' (SW: 6, 463). Różnica morfologiczna występująca między wariantami „stróżowszczyzna” a „strożewszczyzna” może mieć związek $\mathrm{z}$ pochodzeniem autora aktu. Jan Lutomirski bowiem wywodził się z południowej Wielkopolski, był kasztelanem sieradzkim, jego mowę mogła zatem charakteryzować oboczność -ow // -e’w; przejście to mogło być również cechą języka pisarza kancelaryjnego, który wprowadzał akt do księgi kancelaryjnej.

Kolejną nazwą powinności, zanotowaną przez autora wołyńskiego dokumentu, jest prochowszczyzna. Formy prochowszczyzna nie odnajdujemy w żadnym opracowaniu leksykograficznym, interpretujemy ją jako regionalny odpowiednik podatku zarejestrowanego w SPXVI pod nazwą „prochowe”. Przy czym należy zauważyć, że nazwa „prochowe” po raz pierwszy została odnotowana dopiero w XVI wieku i dla tego stulecia potwierdzona ledwie jednym przykładem zaczerpniętym z Lustracji województw wielkopolskich i kujawskich 1564-1565, a kontekst, w którym omawiany termin został użyty, stał się podstawą do sformułowania jedynie bar- 
dzo ogólnej definicji: 'bliżej nieznany rodzaj opłaty, być może składanej na proch' (SPXVI: 30, 320). Leksykograficzne dzieje wyrazu dowodzą, że w późniejszym okresie, wraz z upowszechnieniem się broni palnej, nazwa "prochowe” stała się elementem specjalistycznej terminologii łowieckiej, rzecz jasna, także zróżnicowanej terytorialnie. W Słowniku wileńskim wyraz „prochowe” został zdefiniowany jako "kara pieniężna, zasądzana służbie leśnej, za zastrzelenie w lesie ogara lub charta, użytego do łowów' (SWil: 1021), w Słowniku warszawskim natomiast jako: 'nagroda pieniężna, którą strzelec za ubitego zwierza dostaje, strzałowe' (SW: 4, 1007). Jedynie SJPD dla nazwy „prochowe” podaje definicję: 'opłata pieniężna zamiast składania prochu', którą opatruje kwalifikatorem „dawniej” i uzupełnia cytatem z Miast i mieszczaństwa w dawnej Polsce Jana Ptaśnika: „Od roku 1631 jednak w miejsce składania prochu [...] wprowadza się opłatę pieniężną, zwaną prochowe, obliczając wartość kamienia prochu na 14 zł". Nienotowana w opracowaniach leksykograficznych forma prochowszczyzna w nieco późniejszym okresie została licznie poświadczona w Inwentarzach na wybieranie czynszu we włości starostwa czeczerskiego ${ }^{9} \mathrm{z} 1704$ oraz 1769 roku (Dowgiałło 1900: 4-81), gdzie prawie zawsze (kilkadziesiąt razy) występuje w szeregu „prochowszczyzna i stróżowszczyzna”. Wydawca inwentarzy zwraca uwagę, że podatku zwanego prochowszczyzną nie płacili bojarzy, a jego wysokość w starostwie czeczerskim wynosiła po 26 groszy z każdego dymu (Dowgiałło 1900: VII).

W rozliczeniach towarzyszących przekazaniu zamku w Ostrogu wystąpił jeszcze inny interesujący termin - wy r ząd. Leksem ten w Sstp został potwierdzony cytatem z 1439 roku i wyjaśniony definicją: '(termin używany na Rusi Czerwonej) danina, którą kmiecie zobowiązani byli złożyć panu wyruszającemu na wojnę’ (Sstp: 10, 546). Wydaje się, że leksykografowie nie dysponują żadnym poświadczeniem tego wyrazu dla XVI stulecia, wyrząd nie występuje bowiem w indeksie haseł SPXVI. Wyraz nie został też zarejestrowany w ESJPXVII, z kolei L: 6, 588, Swil, 2008, SW: 7, 1016 notują hasło w innym znaczeniu.

Ostatnią nazwą powinności w przytoczonym wcześniej zdaniu z aktu zarejestrowanego w Metryce Koronnej jest kuniczne. Również i ta forma nie jest notowana w SPXVI. Spośród opracowań leksykograficznych rejestruje ją jedynie Słownik warszawski, w którym występuje jako synonim leksemu „kunica” (SW: 2, 632). W dokumencie sporządzonym w Ostrogu odnajdujemy obie nazwy powinności: wspomniane kuniczne oraz kunicę. W dziejach języka polskiego leksem kunica służył nazywaniu kilku zupełnie różnych danin. Na Rusi oznaczał 'opłatę na rzecz pana feudalnego uiszczaną za dziewczynę, wychodzącą za mąż do innej wsi lub miasta. Takie wyjaśnienie terminu podaje już Sstp i dokumentuje je zapisem z 1447 (Sstp: 3, 462). Rejestruje je również SPXVI, który przywołuje za Słownikiem

${ }^{9}$ Czeczersk - miasteczko w powiecie rohaczewskim nad rzeką Sożą (por. Sulimirski, Chlebowski, Walewski 1880: 1, 782). 
Lindego interesujący cytat ze Sposobu osady nowego Kijowa (1595) Józefa Wereszczyńskiego:

gdy pánná miefscka idzie zá mąż z miáftá Kiiowfkiego/ ták z ftárego iáko y z nowego ná I.K.M. ofádzonych/żeby powinien był Nowożenia każdy Horodniczemu zamku Kiiowlkiego/ Kunicy puł złotego/ á gdy wdowę poymuie/ był też powinien dáć złoty Polfki. Z ktorych to Kunic/ Horodniczy káżdy zamku Kiiowfkiego ma mieć swoie opatrzenie. (SPXVI: 11, 547)

Znaczenie to odnotowują także inne słowniki: L: 2, 547, SWil: 564, SW: 2, 632 oraz SJPD.

Autor dokumentu z Wołynia istotę opłaty nazwanej raz kunicą, a raz zleksykalizowanym przymiotnikiem kuniczne, ujął w słowa, wyszczególniając rozmaite źródła przychodów: „z wdow i z dziewek czo za mąz do siol idą” (k. 362 v.). Ilustracji wystąpienia leksemu kunica służy zaś inny fragment aktu:

potim gdim chczial Ia Luthomirski abi mi then to Raiewicz z infchich iefcze rzeczi o pozithkow [sic!] oftrofkich liczbą vczinil od swiantego Barthlomieia blifko przifflego tho ieft $\mathrm{z}$ win, przesandow z mieifkich kunicz... (k. 362 v.)

W tym zdaniu zostały przytoczone ponadto inne nazwy powinności, takie jak przesąd i wina. Termin przesąd oznaczał 'opłatę sądową, wynagrodzenie za sądzenie sprawy; koszta sądowe, prawne; grzywnę, winę'. Leksem ten nie został jak dotąd udokumentowany dla XVI wieku ani dla okresu wcześniejszego; autorzy SPXVI sygnalizują jedynie wystąpienie rzeczownika przesąd w słownikach Knapiusza i Lindego, ale z przykładami dopiero z XVII (XVIII)-XVIII wieku (SPXVI: $32,155)$. Interesujące nas znaczenie leksemu potwierdzają natomiast następujące opracowania leksykograficzne: L: 4, 580, Swil: 1258, SW: 5, 188, SJPD.

Następny termin, wina, w Słowniku staropolskim wyjaśniony został definicją: 'kara, zwłaszcza pieniężna, może też opłata z racji różnego rodzaju zobowiązań (Sstp: 10, 225). Leksem notowany jest $\mathrm{w}$ indeksie haseł SPXVI i ESJPXVII, ale samo hasło w żadnym $\mathrm{z}$ tych słowników nie zostało jeszcze opracowane. W znaczeniu prawniczym jako 'karę pieniężną płaconą sądowi przez skazanego' wyraz rejestrują następujące słowniki: SWil: 1861, SW: 7, 614, SJPD. Autor prezentowanego w tym artykule dokumentu z Metryki Koronnej posłużył się określeniem win a kilkukrotnie i stosował je nie tyle w odniesieniu do kary sądowej, ile do rozmaitych zobowiązań, co między innymi dokumentuje ten oto przykład: „i thez abi liudziom oprawili Raievicz s tupilem czo ich pograbili i winy niefluffne pobrali, iako tich krziwd liudzkich regeftr pod naffemi pieczącziami ieft spifan” (k. 362 v.).

Kilka kolejnych nazw powinności z dokumentu przekazania zamku w Ostrogu odzwierciedla zwyczaje i uregulowania prawne związane z wymianą towarową. Do grupy tej należy między innymi powszechnie używany od XV wieku leksem myto: 'opłata pobierana w naturze lub monecie za przewóz towarów na drogach wodnych i lądowych, także opłata celna na granicach kraju' (SPXVI: 15, 296). W dokumencie z Ostroga rzeczownik myto wystąpił kilka razy, oto jeden z przykładów: 
z naimowich Mlinow mita kapfczizni, i Targowego ktore naiantho bilo zidom oftrofkim od panni Mariei zwiaftowania roku MDXLI az do swiathego piotra roku MDXLII przez rok, i nÿedziel trzinafczie, i dnÿ piancz za kop siedmfet i czterdziefczi kop moneti Litewfki. (k. 359 v.)

Inaczej niż to się działo w Koronie, gdzie prawo zabraniało najmowania ceł Żydom (por. Berkowski 2009: 221), cła i myta na Wołyniu dzierżawili przeważnie celnicy żydowscy (Berkowski 2009: 226). Oprócz państwowych komór celnych po całym województwie wołyńskim rozsiane były liczne komory prywatne, w których pobierano różnego rodzaju myta, uznawane za środek łatwego zwiększenia dochodów właścicieli osad. W analizowanym dokumencie odnotowano także połączenie wyrazowe myto zasławskie, co ilustruje następujący cytat:

s ktorei su(m)mi zraziwffi pierwei mitho zaflawfkie ktore na komorze oftrofkiei przichodzi Cro. iei mczi podlie Regeftrow zidowfkich i czelnika kop ofmdziefianth ÿ schefcz, i trzidziefczi i czterzi groffe. (k. 359 v.)

W tekstach z XVI wieku w zasadzie nie rozróżnia się znaczenia pojęć my ta i cła. SPXVI cło definiuje jako 'opłatę pobieraną za wwóz i wywóz towarów przeznaczonych na handel, także inne opłaty na rzecz państwa' (SPXVI: 3, 533). Choć w komorze w Ostrogu pobierano opłatę nazwaną tu mytem zasławskim, to związany z tą instytucją urzędnik określony został jako pisarz cła zasła wskieg o, co pokazuje poniższy fragment: „zeznawami thim tho liftem przed wffithkiemi komu thego potrzeba bandzie iz przi panie Staniflawie Narbuczie pifarzu czla zaflawskiego Cro. iei Mczi na komorze oftrofkiei" (k. 351).

Następnym terminem związanym z wymianą towarową jest targo we - 'opłata od sprzedawanych na targu towarów uiszczana przez przekupniów, opłata za przyjazd na targ i udział w nim, za korzystanie z targu' (Sstp: 9, 122-123), uznawane za jedną z dwóch najstarszych nazw powinności w języku polskim (por. Zajda 2007: 52). W omawianym dokumencie z Metryki Koronnej wystąpiła też nazwa targo we mięsne albo mięśne (pisarz nie oznacza miękkości spółgłosek przed inną spółgłoską) - 'opłata od sprzedawanych tuszy bydła i mięsa w ogóle. O istnieniu na Wołyniu opłaty o nazwie mięsne wspomina Władysław Berkowski, powołując się na ustalenia ukraińskiej badaczki Metryki Litewskiej S. Abrosymowej. Podał on, że opłatę tę nazywano niekiedy targowy m oraz że w Ostrogu w 1620 roku od mięsa, „które z siół przywożą”, pobierano łopatkę (Berkowski 2009: 230). Na podobną wysokość opłaty zdaje się wskazywać również autor omawianego tu dokumentu w charakterystycznej dla ówczesnej epoki konstrukcji ze spójnikiem „albo”: „s targowe(g) o mią̧n ego albo za pliecze” (k.362 v.), w której „albo” znaczy 'czyli', „plece” natomiast, będące formą liczby mnogiej rzeczownika „plec”, w odniesieniu do zwierząt oznaczają 'część przedniej nogi przylegającą bezpośrednio do tułowia, czyli łopatkę' (por. SPXVI: 24, 328). W opracowaniach leksykograficznych termin mięsne notowany jest jedynie w SPXVI, w którym został opatrzony definicją 'opłata pieniężna wnoszona przez chłopów na rzecz pana zastępująca dawną daninę w mięsie’ i potwierdzony niewielką liczbą wystąpień, przy czym wszystkie 
one pochodzą z jednego źródła, jakim jest Lustracja województwa sandomierskiego 1564-1565 (SPXVI: 14, 146).

Kolejną nazwą powinności zapisaną w dokumencie z 1542 roku jest targowe groszowe. Termin groszowe dla okresu staropolskiego zdefiniowany został bardzo ogólnie: 'rodzaj daniny pieniężnej złożonej z groszy' (Zajda 1970: 109). Nazwa ta nie jest jednak notowana w SPXVI. Rejestruje ją natomiast SW, który uwzględnia kilka obszarów jej występowania: 1. 'rodzaj podatku na korzyść miasta od piwa'; 2. 'opłata zwyczajowa, składana na przykład pisarzom leśnym przez robotników, pracujących przy wyrębie lasu'; 3. z kwalifikatorem "górnicze”, jako 'opłata po groszu dla króla od każdej niecki wydobytej rudy, opłata dla żupnika od osądzonej sprawy' (SW: 1, 914). W dokumencie z Ostroga groszowe, będące rodzajem powinności związanej z odbywanym targiem, zostało uzupełnione dodatkową informacją: „s targ ow ego groffowe od bidla sielfkiego" (k. 362 v.). Być może chodzi o występującą na Wołyniu opłatę, w ruskich źródłach określaną mianem „spaszne”, której znaczenie Berkowski wyjaśnia jako 'myto od bydła przyprowadzanego na targ, czyli jarmark miejski, które przez pewien czas wypasano na pastwiskach miejskich' (Berkowski 2009: 230).

Spośród nazw obciążeń utrwalonych na piśmie przy okazji przekazywania zamku w Ostrogu wymienić jeszcze trzeba kapszczyznę - 'podatek pobierany za prawo pędzenia wódki lub piwa; czopowe.' $\mathrm{W}$ prezentowanym dokumencie termin kapszczyzna został użyty dwa razy, oto jeden z ilustrujących przykładów:

potim dnia trzidzieftego pirwego wthorego i trzecziego Ianuaria ia Luthomirfki przi tich tho paniech wiffei pifanich przÿmowalem lidzbą od vrządnikow folwarkowich i thiwonow, i tudziez od zidow czo na arendą fwoią mita i kapfczizni ÿ mlinow oftrofkich xÿandzu vaffilu i urzandnikom iego m(iłoś)czi oftrofkim oddali. (k. 356 v.)

Leksem kapszczyzna nie jest notowany w Sstp ani w SPXVI, rejestruje go natomiast L: 2, 311-312, SWil: 468, SW: 2, 250 oraz SJPD. W dwóch ostatnich słownikach leksykografowie dodatkowo zamieścili informację o etymologii wyrazu od średniowieczno-łacińskiego capagium - 'rodzaj poboru, pomoc pieniężna'.

Ponieważ zarówno Podlasie, jak i Wołyń do 1569 roku wchodziły w skład Wielkiego Księstwa Litewskiego, warto nadmienić, że w Lustracjach województwa podlaskiego 1570 i $1576 \mathrm{w}$ funkcji opłaty od warzenia i sprzedaży trunków używana była podobna pod względem fonetycznym nazwa „kapczyzna”, poza tą Lustracją niepotwierdzona innymi wystąpieniami. Autorzy SPXVI formę „kapczyzna” uznali za wariant innego terminu, „kopczyzny”, związany z akaniem na podłożu białoruskim, przy czym nie wykluczyli również etymologii od „kapać” w związku z destylacją alkoholu (SPXVI: 10, 616-617).

Ostatnim terminem nazywającym ciężary feudalne z dokumentu z 1542 roku jest wołowszczyzna, regionalny odpowiednik nazwy „wołowe”, oznaczający 'pieniężny ekwiwalent powinności składania w daninie wołu, jako formy stacji dla wyżywienia przebywającego w okolicy dworu królewskiego’ (por. hasło „wołowe” w: 
Zajda 1970: 202). Użycie tego leksemu ilustruje poniższy cytat: „a z wolowfczizni ktorą na krolia ie(g)o mi(łoś)cz wibierali podlie fwich regeftrow, zoftali z liczbi kop fto i fchefcz kop i pianczdziefiant groffi i dwa grofcha, i piancz pienÿądzi” (k. 359 v.). Indeks haseł SPXVI nie uwzględnia rzeczownika wołow szczy zna. Spośród opracowań leksykograficznych formę tę rejestruje jedynie Stownik warszawski, który definiuje ją jako 'pobór od wołów' (SW: 7, 695).

Językowym odzwierciedleniem stosunków ekonomicznych opisywanych terenów są także przymiotniki dańny (albo danny) - 'czynszowy' (SPXVI: 4, 493) oraz dziesięcinny - 'odnoszący się do dziesięciny' (SPXVI: 6, 433), co ilustrują przykłady: „owfa dannego czo wiwieziono i ftrawiono ieft pianczfeth miarek i ofmdziefianth i pancz miarek po dwa grofa czini dziewianthnafczie kop, i trzidziefczi groffl” (k. 360 v.); ,jalowicz dannich wibrano dwie za ktore kopa groffi iedna” (k. 361); „owiecz dziefiączin nich sefczdziefianth schaczuÿancz po schefczi groffi czini ofm kop groffi” (k. 361 v.); „wieprzow dziefiączinnich sto i ofmdziefianth schaczuiączii po dwadziefczia groffi czini pianczdziefianth i trzi kopi i dwadziefczia groffi" (k. 362).

Relacjonując rozliczenia towarzyszące przekazaniu zamku w Ostrogu, autorzy dokumentu wprowadzili do tekstu tylko niektóre nazwy danin, inne zaś powinności feudalne przedstawili opisowo, jak pokazuje to podany niżej fragment:

z loiu od rzeznikow z foli od wozow czo chlopi daią, z niewiaft czo chlieb pieką po piączi groffi, s paftuchow mieifkich, s pieniądzÿ i z owfa $\mathrm{z}$ schewczow czo boti daią, $\mathrm{s}$ kowaliow czo siekieri daią $\mathrm{z}$ wdow, i z dziewek czo za mąz do siol idą, od zonek rozwodnich s targowego z rib, i s wffeliakich stathkow. (k. 362 v.)

Pewnego komentarza może wymagać opłata „od żonek rozwodnych”, obrazująca obyczajowość, a zarazem osobliwość prawną Wielkiego Księstwa Litewskiego. Otóż jednym ze znaczeń leksemu „żonka” odnotowanym w Sstp jest 'kobieta żyjącą bez ślubu z mężczyzną (Sstp: 11, 597). W środowisku prawosławnym zarówno na ziemiach białoruskich, jak i ukraińskich małżeństwo przez długi czas ujmowane było jako umowa świecka. Obok małżeństw zawieranych w cerkwi istniały też tak zwane małżeństwa „niewieńczone”, które powstawały przez rozpoczęcie trwałego pożycia i w opinii społecznej były uznawane za legalne bez żadnych dodatkowych potwierdzeń (Bardach 1970: 261). Takie związki najliczniejsze były wśród chłopów, ale występowały we wszystkich warstwach ówczesnego społeczeństwa W źródłach historycznych pozostały niekiedy wzmianki o specjalnych daninach pieniężnych składanych panu feudalnemu za wzięcie sobie żonki, na przykład w starostwie barskim była to „pojemszczyzna”, a w starostwie ratneńskim na Wołyniu - „poczerewszczyzna" (por. Bardach 1970: 269-270).

Przy okazji przekazania zamku w Ostrogu w oficjalnym dokumencie zapisane zostały liczne nazwy powinności ciążące na poddanych okolicznych ziem. Obok terminów powszechnie używanych $\mathrm{w}$ tym czasie również w Koronie, takich jak arenda, cło, dochód, myto, najem, płat, targowe czy wina, zanotowane zostały również formy rzadkie, w źródłach leksykograficznych dla XVI udokumen- 
towane dotychczas niewielką liczbą wystąpień, jak choćby komorne, łaziebne, mięsne. W zebranym materiale znalazły się również nazwy niepotwierdzone dotychczas dla XVI stulecia, jak na przykład groszowe czy przesąd. W tej grupie są też regionalizmy utworzone charakterystycznym dla Rusi i pogranicza sufiksem -szczyzna od bardziej lub mniej rozpowszechnionych podstaw, na przykład kapszczyzna, podymszczyzna, prochowszczyzna, strożewszczyzna, wołowszczyzna. Regionalny charakter mają również termin wyrząd oraz kunica i derywowana od niej, nieznana gdzie indziej, forma kuniczne. Zebrany materiał pozwala też na weryfikację datowania żywotności formy wyrząd oraz pojawienia się w języku polskim leksemów kapszczyzna i przesąd.

\section{Podstawa źródłowa artykułu}

Metryka Koronna 65, k. 350 v.-364, http://agadd2.home.net.pl/metrykalia/MK/0065/ (dostęp: 10.12. 2020).

\section{Bibliografia}

Bardach J. (1970): Studia z ustroju i prawa Wielkiego księstwa Litewskiego XIV-XVIII w., Warszawa. Berkowski W. (2009): Wołyń w systemie celnym Wielkiego Księstwa Litewskiego i Korony Polskiej (XVIpołowa XVII wieku), „Europa Orientalis. Studia z Dziejów Europy Wschodniej i Państw Bałtyckich" 1, s. 217-233, https://etalpykla.lituanistikadb.lt/object/LT-LDB-0001:J.04 2009 13671790 48615/J.04 2009 1367179048615.pdf (dostęp: 15.03.2021).

Chynczewska-Hennel T. (1979): Ostrogski Konstanty Wasyl, [hasło w:] Polski słownik biograficzny, t. 24, Wrocław, s. 489-495.

Dowgiałło D. (oprac.) (1900): Историко-юридическіе матеріалы, извлеченные изъ актовыхъ книгъ губерній витебской и могилевской, Witebsk, http://starieknigi.info/Knigi/I/Istoriko_yuri dicheskie_materialy_iz_Aktovyh_knig_gubernij_Vitebskoj_i_Mogilevskoj_28_1900.pdf (dostęp: 20.02.2021).

Herbarz polski Kaspra Niesieckiego S.J. powiększony dodatkami z późniejszych autorów, rękopisów, dowodów urzędowych $i$ wydany przez Jana Nepomucena Bobrowicza, t. 7, Lipsk 1841.

Kowalska H. (1973): Lutomirski Jan, [hasło w:] Polski słownik biograficzny, t. 18, Wrocław-Warszawa-Kraków-Gdańsk, s. 139-141.

Przeździecki A. (1868): Jagiellonki polskie w XVI wieku. Obrazy rodziny i dworu Zygmunta I i Zygmunta Augusta Królów Polskich, t. 2, Kraków.

Sulimirski F., Chlebowski B., Walewski W. (red.) (1880): Słownik geograficzny Królestwa Polskiego i innych krajów słowiańskich, t. 1, Warszawa.

Sułkowska-Kurasiowa I., Woźniakowa M. (oprac.): Inwentarz Metryki Koronnej. Księgi wpisów i dekretów polskiej kancelarii królewskiej z lat 1447-1795, http://www.agad.gov.pl/inwentarze/Metr_Korx. xml\#series5 (dostęp: 3.01.2021).

Świeżawski A. (1968-1969): Kościelecka (z Kościelca) Katarzyna, [hasło w:] Polski słownik biograficzny, t. 14, Wrocław-Warszawa-Kraków, s. 397-398.

Zajda A. (1970): Nazwy staropolskich powinności feudalnych, danin i opłat (do 1600 roku), „Zeszyty Naukowe UJ. Prace Językoznawcze", z. 60. 
Zajda A. (2007): Ogeografi nazw staropolskich powinności feudalnych, danin i opłat i jej uwarunkowaniach, „LingVaria” nr 1, s. 51-63. http://www.lingvaria.polonistyka.uj.edu.pl/documents/5768825/bb4a476f -d45c-4ea5-95fb-89f7c8adb24c (dostęp: 20.01.2021).

Żelewski R. (1979): Ostrogski Ilia (Eliasz), [hasło w:] Polski słownik biograficzny, t. 24, Wrocław, s. 480481.

Żelewski R. (1959-1960): Górkowa Elżbieta, [hasło w:] Polski słownik biograficzny, t. 8, Wrocław-Kraków-Warszawa, s. 424-426.

Żelewski R. (1973): Łaska 1. v. Ostrogska z Kościeleckich Beata, [hasło w:] Polski słownik biograficzny, t. 18, Wrocław, s. 222-224.

\section{Rozwinięcie skrótów}

ESXVII: Elektroniczny słownikjęzyka polskiego XVII i XVIII wieku, https://sxvii.pl/ (dostęp: 20.02.2021). L: Linde S.B. (1854-1860): Słownik języka polskiego, t. 1-6, Lwów.

SJPD: Doroszewski W. (red.) (1958-1969): Słownik języka polskiego, t. 1-11, Warszawa, http://www. sjpd.pwn.pl/ (dostęp: 20.02.2021).

SPXVI: Mayenowa M.R., Pepłowski F. (red. t. 1-34), Mrowcewicz K., Potoniec P. (red. t. 35-36) (19662012): Słownik polszczyzny XVI wieku, t. 1-36, Wrocław-Warszawa-Kraków.

Słownik polszczyzny XVI wieku - edycja internetowa, https://spxvi.edu.pl/ (dostęp: 15.02.2021).

Sstp: Urbańczyk S. (red.) (1953-2002): Stownik staropolski, t. 1-11, Kraków.

SW: Karłowicz J., Kryński A., Niedźwiedzki W. (1900-1927): Słownik języka polskiego, t. 1-8, Warszawa.

Swil: Zdanowicz A. (red.) (1861): Słownik języka polskiego, t. 1-2, Wilno, https://eswil.ijp.pan.pl/ (dostęp: 20.02.2020).

\section{The names of feudal dues, payments and levies used in the deed of transfer of the Ostróg castle in Volhynia from 1542}

Summary

The source basis for the article is the deed of transfer of the Ostróg castle in Volhynia from 1542, entered into the Crown Register No. 65. This handwritten document contains interesting vocabulary related to the material and socioeconomic culture of the area. The article discusses the part of the lexicon used to name feudal dues, payments and levies. Apart from the terms commonly used in Poland at the time, also some rare words and regional forms characteristic of Lithuanian and Russian lands that had not been documented for the 16th century in earlier lexicographic studies on the subject are presented.

Keywords: historical lexicography, specialist vocabulary, regionalisms, names of dues, Easternborderland Polish language, Volhynia. 